\title{
Azo Dye Mineralization by Phanerochaete Chysosporium in a Sequencing Bath Reactor
}

\author{
Carlos Ronald Pessoa Wanderley¹, Marcus Vinícius Andrade², Luciana José Pereira³ , \\ Gloria Maria Marinho Silva ${ }^{4}$, Kelly Rodrigues Pessoa ${ }^{4 *}$ \\ ${ }^{1}$ Ceara Federal Institute of Education Science and Technology - Maracanau campus - Coordination of Chemistry \\ and Environment, Maracanau, Ceará, Brazil; ${ }^{2}$ Ceara Federal Institute of Education Science and Technology - \\ Sobral campus, Sobral, Ceará, Brazil; ${ }^{3}$ University of Minho - Center of Biological Engineering Braga Portugal; ${ }^{4}$ \\ Ceara Federal Institute of Education Science and Technology - Fortaleza campus - Department of Chemistry and \\ Environment Fortaleza, Ceará, Brazil.
}

\begin{abstract}
The mineralization of the azo dye congo red by the fungi Phanerochaete chrysosporium was studied in two sequential batch bioreactors (R1 and R2), operated in cycles of 48 h (step I) and 24 h (step II). In step I, glucose concentration was 1 g. $L^{-1}$ in both reactors and in step II, 1 g. $L^{-1}$ of glucose was maintained in $R 1$, but $R 2$ received no addition of glucose. In step I, the average dye removal efficiencies were $76 \pm 29 \%(R 1)$ and $53 \pm 15 \%$ (R2), while in step II the averages recorded for dye removal for RI and R2 were $84 \pm 15$ and $70 \pm 28 \%$, respectively. The rates of dye removal were $0.04 h^{-1}$ in $R 1$ and $0.03 h^{-1}$ in $R 2$ in step I. Higher rates were obtained in step II, 0,07 h-1 and $0,02 h^{-1}$ for $R 1$ and $R 2$, respectively. The highest dye removal occurred in $R 1$ and, in $R 2$, the residual dye was further removed. Laccase was the oxidised at higher amount, in step I was 54 بmol.min ${ }^{-1}$ for RI and $38 \mu m o l m i n^{-1}$ for R2. The proposed treatment system was very effective in removing the azo dye, however the mineralization may not be complete and some by-products may have been formed, according to spectrofotometric analysis, were the peak corresponding to benzene, $220 \mathrm{~nm}$, persisted.
\end{abstract}

Keywords: Biodegradation; Congo red; Phanerochaete chrysosporium; Sequential bioreactors

*Author for correspondence: kellyarpessoa@gmail.com 


\section{INTRODUCTION}

The pollution increased pollution in rivers, lakes and reservoirs with xenobiotics compounds puts at risk the balance of the aquatic biota. In addition, there is a decrease of water quality of water sources intended for human consumption, due to their toxicity and carcinogenic and mutagenic effects ${ }^{1}$.

Textile activities are among those contribute contributing most to the contamination of aquatic environments with recalcitrant compounds. Another negative aspect is that textiles processes require large amounts of water, dyes and chemicals along a complex supply chain and generates large quantities of colored effluents with high organic load 2.

Those effluents are very difficult to treat due to changes in its composition and the presence of strong colors, which if not properly removed, result in serious problems to the environment, causing harm to the photosynthesis algae. The dyes are visible in small quantities and the color has been observed in the aquatic environmental when it is above $1 \mathrm{mg} . \mathrm{L}^{-1}$. Dyes are generally found in wastewater at concentrations ranging from 10 to $50 \mathrm{mg} . \mathrm{L}^{-13}$. Furthermore, some of applied dyes, in special the azo type and their byproducts, can be carcinogens and mutagens. Currently, this class of dyes is about $60 \%$ of the world market and are widely used in the dyeing of textile fibers ${ }^{4}$.

Azo dyes are classified as environmentally hazardous materials due to their toxicity and for this reason there are the need of the treatment of textile effluents to minimize impacts on the environment and human health. However, the anaerobic biological effluent treatment are not efficient for the degradation of dyes, with generation of aromatics amines from breaking of the molecular structure of the azo dyes, which have toxic potential. In addition, physical and chemical methods have been used to remove dyes, but have a high cost which makes its application on a large scale impractical ${ }^{5,6}$.

Thus, the use of fungi for the treatment of effluent can be an alternative due to the ability of these microorganisms to mineralize compounds pollutants through the production and release of non-specific extracellular enzymes with high oxidative power, which are responsible for the biodegradation, transformation, and reduction of dye toxicity ${ }^{7}$.

The complete mineralization of textile dyes by biological treatments is still a challenge, since in most cases the rupture of the azo bond occurs without efficient degradation of other components of structures of the dye molecule, which still results in the presence of compounds that can have harmful effects on the environment ${ }^{8}$. In order to optimize the mycoremediation process for highest mineralization of azo dye congo red, Phanerochaete chrysosporium, a potent white rot fungus, was used in sequencing batch reactors arranged in series.

\section{MATERIAL AND METHODS}

\section{Production of fungal spores}

Phanerochaete chrysosporium was grown in Petri dishes containing culture medium which had the following composition $\left(\mathrm{g} . \mathrm{L}^{-1}\right)$ : yeast extract (2), glucose (20), $\mathrm{K}_{2} \mathrm{HPO}_{4}$ (20), $\mathrm{KH}_{2} \mathrm{PO}_{4}(0,6), \mathrm{MgSO}_{4}(0,5)$ and peptone (2). The plates inoculated with fungi were kept at $28^{\circ} \mathrm{C}$ in an incubator for seven days and after this time, the spores were removed by using an isotonic saline plus Tween 80 solution and transferred to test tubes ${ }^{9}$. For counting the spores, a solution was prepared using $50 \mu \mathrm{L}$ of the spores suspension. The spores concentration in the suspension was determined according to the equation below. 
Spores $/ \mathrm{mL}=$ number of spores counted $\mathrm{x}$ dilution $\times 2,5 \times 10^{5}$

\section{Fungal Imobilization}

The fungal was immobilized on polyurethane foam cubes $(1 \mathrm{~cm}$ edge). Five grams of foam previously sterilized were placed in a permeable polyethylene network which was subsequently brought into erlenmeyers containing nutrient medium. Then the flasks were inoculated with fungal spores at concentration of $2 \times 10^{6}$ espores. $\mathrm{mL}^{-1}$. The nutritive medium had the following composition (g.L $\left.\mathrm{L}^{-1}\right)$ : glucose (5.0); $\mathrm{NaNO}_{3}$ (0.25); $\mathrm{MgSO}_{4} .7 \mathrm{H}_{2} \mathrm{O}$ (1.0); $\mathrm{CaCl}_{2} . \mathrm{H}_{2} \mathrm{O}$ (0.04); $\left(\mathrm{NH}_{4}\right)_{2} \mathrm{SO}_{4}(0.5) ; \mathrm{KH}_{2} \mathrm{PO}_{4}$ (2.0); $\mathrm{H}_{2} \mathrm{MoO}_{4}(0.02) ; \mathrm{MnSO}_{4}(0.02) ; \mathrm{Fe}_{2}\left(\mathrm{SO}_{4}\right)_{3}(0.02)$ and $\mathrm{ZnSO}_{4} .7 \mathrm{H}_{2} \mathrm{O}$ (0.01). The flasks remained under stirring at $150 \mathrm{rpm}$ for $48 \mathrm{~h}$, after this period, the culture medium was replaced and maintained for $72 \mathrm{~h}$ until being transferred to the reactor ${ }^{9,10}$.

\section{Mineral Medium}

The mineral medium used in this study was done with congo red $\left(0.015\right.$ g.L $\left.\mathrm{L}^{-1}\right)$ and macronutrients (g.L $\left.\mathrm{L}^{-1}\right): \mathrm{KH}_{2} \mathrm{PO}_{4}(0.2), \mathrm{MgSO}_{4} .7 \mathrm{H}_{2} \mathrm{O}(0.5), \mathrm{CaCl}_{2} .2 \mathrm{H}_{2} \mathrm{O}$ (0.1) e $\left(\mathrm{NH}_{4}\right)_{2} \mathrm{SO}_{4}(0.2)$. $10 \mathrm{~mL}$ per liter of micronutrients solution containing (g.L $\left.\mathrm{L}^{-1}\right)$ : $\mathrm{MgSO}_{4} \cdot 7 \mathrm{H}_{2} \mathrm{O}(3,0), \mathrm{NaCl}(1,0), \mathrm{MnSO}_{4} \cdot \mathrm{H}_{2} \mathrm{O}(0,5), \mathrm{FeSO}_{4} \cdot 7 \mathrm{H}_{2} \mathrm{O}(0,1), \mathrm{ZnSO}_{4} \cdot \mathrm{H}_{2} \mathrm{O}$ $(0,1), \mathrm{CoCl}_{2} \cdot 6 \mathrm{H}_{2} \mathrm{O}(0,1), \mathrm{CaCl}_{2} \cdot 2 \mathrm{H}_{2} \mathrm{O}(0,082), \mathrm{H}_{3} \mathrm{BO}_{3}(0,01)$ and $\mathrm{CuSO}_{4} .5 \mathrm{H}_{2} \mathrm{O}(0,01)$ were also added ${ }^{9}$. The $\mathrm{pH}$ was adjusted to 5 with the addition of sulfuric acid $5 \mathrm{~N}$, in order to maintain optimal conditions for fungal growth.

\section{Biological sequential batch reactors}

Two reactors were operated in sequential batch. The $\mathrm{R} 1$ reactor was fed with mineral medium and congo red dye (15 mg. $\left.\mathrm{L}^{-1}\right)$. Subsequently, the effluent from R1 was sent to the $\mathrm{R} 2$ reactor for post-treatment. Thus the effluent from reactor R1 was the influent of reactor R2. R1 and R2 reactors were built in glass with reaction volume of $4 \mathrm{~L}$ and $3,5 \mathrm{~L}$, respectively. The content in both reactors was maintained aerated by an aquarium air pump.

The experiment on the reaction time of the operating cycle has been divided into step I (48 h) and II step (24 h). Glucose was the cossubstrate used and in step I each of the reactors received addition of 1 g.. $\mathrm{L}^{-1}$ of this cossubstrate. In Step II, R1 continued to be operated with addition of glucose $\left(1 \mathrm{~g} . \mathrm{L}^{-1}\right)$, but $\mathrm{R} 2$ received no addition of cossubstrate.

\section{Reactors monitorization}

For monitoring the reactors, analysis of $\mathrm{COD}$, dye, $\mathrm{pH}$, ammonia, nitrite, nitrate and activity of manganese peroxidase were made according to APHA ${ }^{11}$. The dye concentration was determined by UV-VIS spectrophotometry by reading the absorbance at $500 \mathrm{~nm}$. A calibration curve was constructed with known concentrations of congo red ( 0 a 50 g... $\left.{ }^{-1}\right)$ prepared in distilled water. Before reading, the samples were centrifuged at $3500 \mathrm{rpm}$ during 15 minutes.

Absorption bands were obtained in samples from the effluent and reactor effluent for the operating cycles studied to evaluate the degree of mineralization of the dye and the formation of by-product. The observation of the bands was done by "scans" between 200 and $800 \mathrm{~nm}$ of the samples filtered in UV-Vis spectrophotometer (Thermo Evolution 100). 
Manganese peroxidase (MnP) activity was made according Aguiar Filho ${ }^{12}$. For that, boiled and not boiled samples $(600 \mu \mathrm{L})$ were placed in test tubes. Then, $50 \mu \mathrm{L}$ of $\mathrm{MnSO}_{4}, 50 \mu \mathrm{L}$ of succinate buffer, $100 \mu \mathrm{L}$ of sodium lactate and $200 \mu \mathrm{L}$ of bovine albumin were added to each tube. The control tube was boiled for 10 minutes and then cooled. The initial time was measured by measuring the absorbance after addition of phenol red $(100 \mu \mathrm{L})$. The final time was measured after 10 minutes after adding $\mathrm{NaOH}(40 \mu \mathrm{L})$. The absorbance was read at $610 \mathrm{~nm}$ and $\varepsilon_{610 \mathrm{~nm}}=44600 \mathrm{~L} \cdot \mathrm{M}^{-1} \cdot \mathrm{cm}^{-1}$.

Laccase activity was with use of the boiled and not boiled sample $(600 \mu \mathrm{L})$, which were added to the test tubes along with citrate-phosphate buffer $(300 \mu \mathrm{L})$. Posteriorly, a control tube was boiled for 10 minutes and after that the tube was cooled. The initial time was measured by absorbance after addition of syringaldazine $(100 \mu \mathrm{L})$. The final time was determined after 10 minutes by reading the absorbance. The samples and controls were read at $525 \mathrm{~nm}^{12}$ and $\varepsilon_{525 \mathrm{~nm}}=65000 \mathrm{~L} \cdot \mathrm{M}^{-1} \cdot \mathrm{cm}^{-1}$.

It was used the following equation to calculate the enzymatic activity (UI.L $\left.{ }^{-1}\right)$ :

$$
\mathrm{UI} / \mathrm{L}=\underset{\varepsilon \times \mathrm{R} \times \mathrm{t}}{-\Delta \mathrm{abs} .} \times 10^{6}
$$

Where: $\Delta$ abs being the variation of absorbance; $\varepsilon$ the molar absorption coefficient $\left(\mathrm{L} . \mathrm{M}^{-1} \cdot \mathrm{cm}^{-1}\right)$; $\mathrm{R}$ is the amount of sample $(\mathrm{mL})$ and $\mathrm{t}$ is the reaction time in minutes. The optical path was $1 \mathrm{~cm}$.

\section{Dye adsorption essays in the biofilms}

A polyurethane cube containing adhered fungal biomass was removed from both reactors to determine the concentration of dye adsorbed to the biofilm. Each cube was transferred to erlenmeyers with saline solution and glass beads. Then the erlenmeyers were shaken vigorously to remove the adhered biomass from support cubes. The aqueous phase containing the removed biomass was centrifuged at $3500 \mathrm{rpm}$ and the supernatant was separated from the biomass. Methanol $(10 \mathrm{~mL})$ was the solvent used to remove the adsorbed dye and was put together with the biomass in test tubes and kept in contact for 10 minutes. After this time, another $5 \mathrm{~mL}$ of methanol was placed in tubes which had their contents homogenized and the absorbance was read at $500 \mathrm{~nm}$ in a spectrophotometer Rayleigh 2601.

\section{Adsorption assay on supports cubes}

Polyurethane cubes $(5.0 \mathrm{~g})$ and $1 \mathrm{~L}$ of basal medium were introduction into a glass vial $(4 \mathrm{~L})$. The polyurethane cubes were previously oven dried. The basal medium had congo red dye $\left(0.05\right.$ g.. $\left.\mathrm{L}^{-1}\right)$. The maximum adsorption capacity for the dye adsorption was measured from the initial concentration of dye in basal medium, with aliquots removal over $48 \mathrm{~h}$.

\section{Kinetic treatment of the data}

The dye concentration data from the operation of batch reactors with dispersed biomass were adjusted according equation below to obtain the dye degradation rate coefficient (k). 


$$
\ln \frac{C}{C o}=-k t
$$

Where Co: initial dye concentration (g.L $\left.\mathrm{L}^{-1}\right)$; C: dye concentration in time "t" (g.L $\left.\mathrm{L}^{-1}\right)$ and $\mathrm{k}$ : dye degradation rate coefficient in first order reaction $\left(\right.$ day $\left.^{-1}\right)$.

\section{RESULTS AND DISCUSSION}

\section{Reaction operation in cycles of $48 \mathrm{~h}$}

\section{Dye and organic matter removal during the step I of operation}

The average concentration of dye in $\mathrm{R} 1$ was $14 \pm 5 \mathrm{mg} \cdot \mathrm{L}^{-1}$ in the influent and $2.8 \pm 2$ mg. $\mathrm{L}^{-1}$ in effluent. R1 effluent was sent to the reactor R2, producing a final effluent with average dye concentration of $1.8 \pm 1.2 \mathrm{mg} . \mathrm{L}^{-1}$. Figure 1 shows the variation dye concentration during the operation of the sequencing batch reactors R1 and R2 in step I.

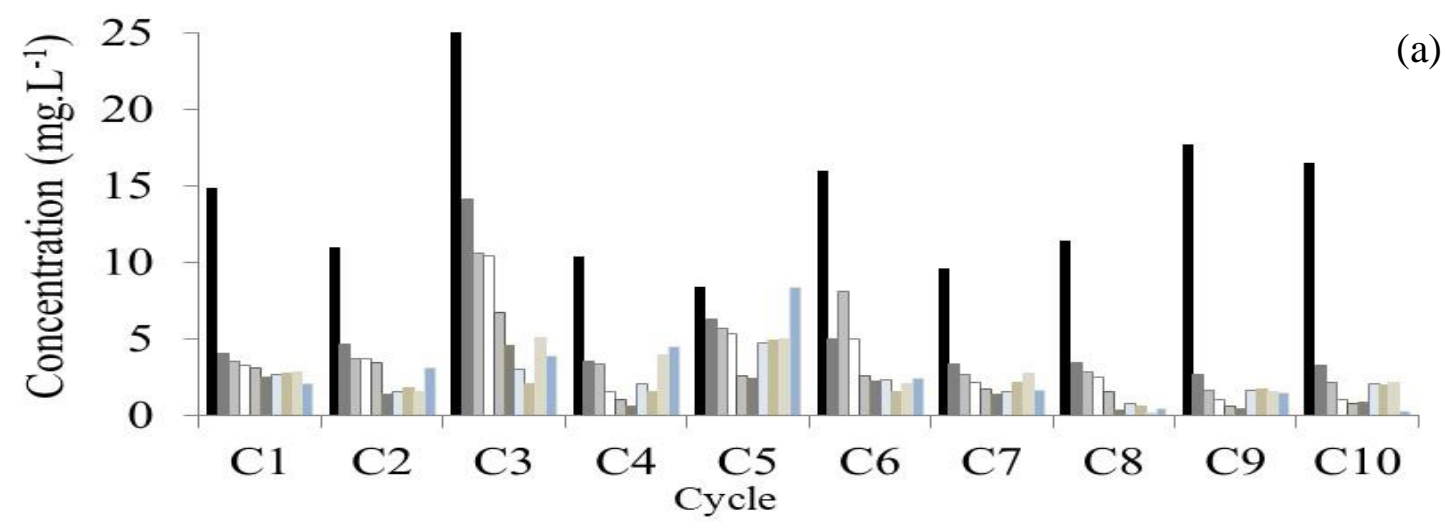

$\square 0 \mathrm{~h} \square 2 \mathrm{~h} \square 4 \mathrm{~h} \square 6 \mathrm{~h} \square 20 \mathrm{~h} \square 24 \mathrm{~h} \square 26 \mathrm{~h} \square 28 \mathrm{~h} \square 30 \mathrm{~h}=48 \mathrm{~h}$

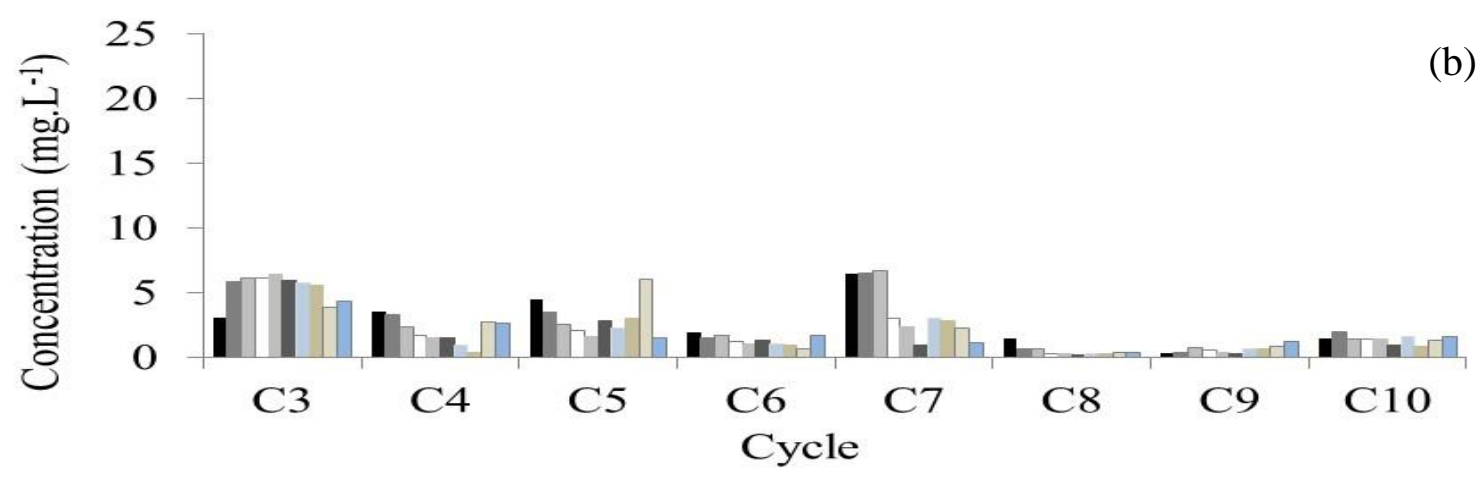

$\square \mathrm{Oh}=2 \mathrm{~h} \square 4 \mathrm{~h} \square 6 \mathrm{~h} \square 20 \mathrm{~h} \square 24 \mathrm{~h}=26 \mathrm{~h} \square 28 \mathrm{~h} \square 30 \mathrm{~h} \square 48 \mathrm{~h}$

Figure 1 - Variation in the dye concentration in the reactors with Phanerochaete chrysosporium immobilized biomass operated in series: (a) $\mathrm{R} 1$ reactor, (b) $\mathrm{R} 2$ reactor.

The dye removals were of $76 \pm 29 \%$ in $\mathrm{R} 1$ reactor and $53 \pm 15 \%$ in $\mathrm{R} 2$ reactor. However, the cycles C3, C9 and C10 of R2 reactor were not considered, because there was an increased in congo red concentration in the medium, 4.33, 1.24 and 1.59 g.L. ${ }^{-1}$, respectively. These increases were due to dye desorption of the biofilm and the 
support cubes. The largest amount of dye was obtained in reactor R1, $99 \%$, which occurred in the cycle 10 . The largest removal in the $\mathrm{R} 2$ reactor was $83 \%$ (cycle 7). In R1 there was no dye removal only during cycle 5, which was due to dye desorption from the biomass. The decrease of congo red concentration happens in the first 30 hours, but after the total reaction time $(48 \mathrm{~h})$, the concentration returned to the initial value, 8.4 g.L $\mathrm{L}^{-1}$.

As can be seen by the spectrophotometric scanning of the samples of the effluent and influent of R1 (cycle 8), the decrease of the band referring to the aromatic fraction, in particularly at the benzene wavelength, $\sim 210 \mathrm{~nm}$, was $36 \%$. Although the bond $-\mathrm{N}=$ $\mathrm{N}$ - has been ruptured and caused the sharp decrease in absorbance at wavelength of $500 \mathrm{~nm}(76 \%)$ in R1 (Fig. 2), the mineralization of the dye was partial. There was persistence of aromatic structures such as benzene, a by-product of the degradation of congo red by Phanerochaete chrysosporium.

In R2, the effluent from most cycles showed an increase of up to $38 \%$ in the absorbance values at the wavelength of the benzene ring $(210 \mathrm{~nm})$ compared to the value recorded for its influent. Interestingly, the effluent from the cycles also showed an increase in wavelength of $\sim 270 \mathrm{~nm}$, possibly relative to the naphthalene presence, which compound has accumulated in the medium. The biodegradation of azo dyes by fungi leads to formation of phenolic by-products, catechols (benzenodiois) subsequently transformed into organic acids such as muconic cis-acid and $\beta$ ketoadipic acid and then mineralized to carbon dioxide, water and new cells ${ }^{13}$.

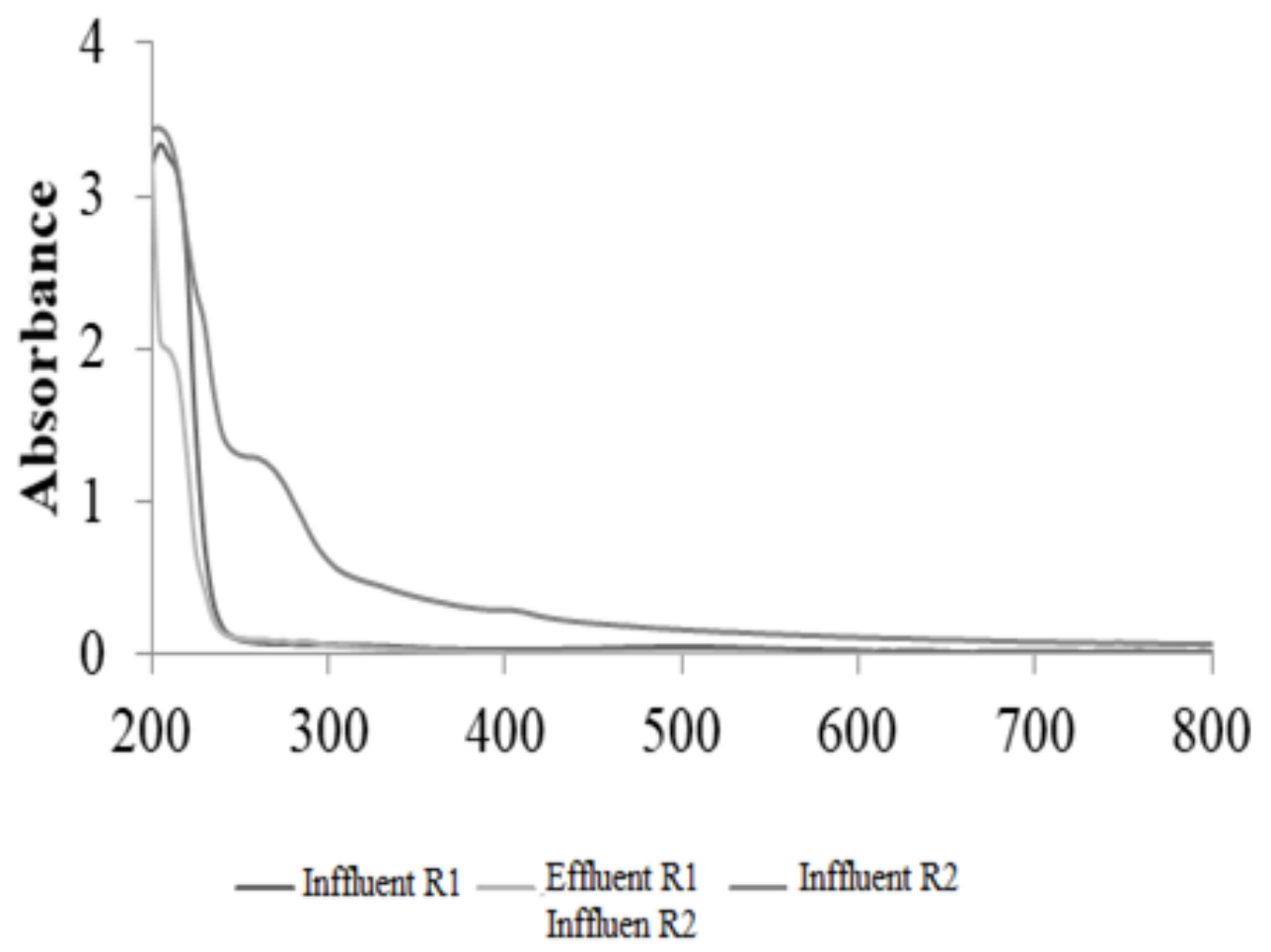

Figure 2 - Scanning the samples, influent R1, effluent R1/influent R2 and effluent R2 in cycle 8.

It is possible that derived organic acids have been generated as byproducts of the partial use of congo red, because for the effluent of $\mathrm{R} 1$ the $\mathrm{pH}$ value was 4.3 , characteristic of acid medium, and ranged from 3.2 to 5.9 throughout the reactor 
operation. In R2, the average values, minimum and maximum effluent $\mathrm{pH}$ was 4.4 and 6.9 , respectively, higher than those found in R1. This was justified because mineralization dye lower in R2.

Concerning the dissolved organic matter, the average removal efficiency was $71 \% \pm$ 25 , the reactor $\mathrm{R} 1$, and $48 \% \pm 26$ in the $\mathrm{R} 2$. The concentration of dissolved organic matter in the R1 reactor influent was between 761 g. $\mathrm{L}^{-1}$ and 947 g.L. $\mathrm{L}^{-1}$, with a mean of 841 g.L $\mathrm{L}^{-1}$. These low percentages of organic matter removal can be explained by the accumulation of by-products in cycles 3 (R1) and 5 (R2), which caused loss of efficiency in the removal of organic matter.

Maximum removals of dissolved organic matter recorded in R1 and R2 were $97 \%$ and $74 \%$, respectively.

In general, lower dye removal percentages were achieved at R2, whose average COD removal efficiency was $42 \% \pm 15$, while that of dye was $53 \% \pm 13$. However, this can be justified because in R2 the dye did not constitute the largest fraction of carbonaceous organic matter, but the aromatic compounds derived from the initial degradation of the dye molecule. Probably this lower enzymatic activity may be related to the toxicity of the by-products formed.

Both laccase and MnP are enzymes produced by white rot fungi in the degradation of different aromatic compounds such as benzopyrene, benzothiophene, anthracene, bisphenols, chlorophenols, among others ${ }^{14}$. However, in this work the highest enzymatic activity was attributed to laccase. As expected, in the reactor R1 was observed greater enzymatic activity than in the R2 reactor. In the first reactor, the laccase reached $54 \mu \mathrm{mol} . \mathrm{min}^{-1}$, an activity superior to that obtained for manganeseperoxidase $\left(6 \mu \mathrm{mol} \cdot \mathrm{min}^{-1}\right)$.

Higher laccase activity was also obtained in R2 $\left(38 \mu \mathrm{mol}^{\mathrm{min}}{ }^{-1}\right)$ than the MnP activity $\left(9 \mu \mathrm{mol} . \mathrm{min}^{-1}\right)$, indicating that it was the main enzyme in dye degradation in RBS reactors in series.

Laccase is an enzyme whose production has been reported in media rich in nitrogen and in the presence of $\mathrm{Mn}^{++}$, as the medium used in this research. In addition, this enzyme is able to catalyze the oxidation of a wide variety of phenolic and nonphenolic compounds, being cited in the color removal of wastewater, such as textile effluents ${ }^{15,16}$. This enzyme is extremely versatile enzymes in the degradation of aromatic compounds such as aromatic hydrocarbons and phenolic compounds ${ }^{14}$.

Champagne and Ramsay (2005) ${ }^{15}$ also reported that media whose laccase: MnP ratio was less than 30, there was good dye removal efficiency (> 90\%). In fact, in both steps the laccase: MnP ratio was lower than the value reported by the authors, with 9 (R1) and 4 (R2) in step I and 13 for R1 and R2 in step II.

Many dyes are substrates for the laccase which acts as a cathode that greatly increases the range of dyes that can be effectively removed from the medium and the rate of removal. Moreover, in the presence of living cells and due to their complete metabolic network, the assimilation of intermediate compounds can occur ${ }^{18}$. These intermediate compounds may be from aromatic amines, carboxylic acids, alcohols and esters derived from the degradation of the dye molecule ${ }^{19}$.

The role of the use of co-substrate in the bioremediation of textile dyes is relevant due to the complexity of the molecular structure of these compounds. The co-substrate has influence on the enzymatic production, as reported by Das et al. $(2016)^{18}$, which obtained higher enzymatic activity of laccase in media containing fructose, sucrose and glucose, with values between 0.5 and $0.6 \mathrm{U}_{\text {.gds }}{ }^{-1}$.

The co-substrate addition occurs until an optimal range of concentration, above which no efficiency is observed in the process of treatment of textile effluents. In the study of Pakshirajan and Kheria $(2012)^{20}$ to the removal of color from an in natura textile effluent, the best response of the system occurred for glucose concentrations between 5 g. $\mathrm{L}^{-1}$ and 10 g.L $\mathrm{L}^{-1}$. The COD/co-substrate relationship is an important factor of the 
process. In this study, in the $\mathrm{R} 1$ reactor that received the highest concentration of dye affluent $\left(14\right.$ g. $\left.\mathrm{L}^{-1}\right)$ and had a COD/glucose ratio of 0.9 , greater enzymatic activity was achieved than in R2. In the second reactor (R2), the dye affluent concentration was 2 g. $\mathrm{L}^{-1}$, with $\mathrm{COD} /$ glucose values of 0.25 and 0.5 , respectively, to $246.5: 1$ and 246.5:0.5.

The average dye removal in R2 did not differ, irrespectively of the decrease in the concentration of glucose added in the post-treatment, from 1 g. $\mathrm{L}^{-1}$ to 0.5 g. $\mathrm{L}^{-1}$. This fact would be related to the inductive character of the dye on the enzymatic activity, so that greater concentration of congo red in R1, triggered the production of higher concentration of enzymes. On the other hand, the dye molecule was not the main pollutant to be degraded in the $\mathrm{R} 2$ reactor, since unidentified by-products were formed in the medium.

The possible presence of catechol as intermediate from the initial degradation of the dye molecule can have difficulted the biodegradation process, because had low ionization potential (IP $)^{13}$. Since the concentration of dye in the affluent of the second reactor was very low $\left(\sim 2\right.$ g. $\left.\mathrm{L}^{-1}\right)$, it is pointed out the importance of the relationship between the concentration of by-products of the dye degradation and that of the cosubstrate to be added. Congo red biodegradation is a complex step process with many unidentified intermediates. However, naphthalene and benzidine are reported as known by-products ${ }^{20}$.

The efficiency of dye and COD removal in the R2 reactor would have been lower due to the presence of by-products with higher molecular stability due to the degradation of the dye in the reactor $\mathrm{R} 1$. As the affluent of reactor $\mathrm{R} 2$ was the effluent from reactor $\mathrm{R} 1$ and contained residual dye $\left(2 \mathrm{mg} . \mathrm{L}^{-1}\right)$, glucose $\left(1 \mathrm{~g} . \mathrm{L}^{-1}\right)$ and by-products of the initial dye degradation, possibly the least dye removal and COD was lower because of the presence of these by-products. Under these conditions, even if glucose was added to the medium, it would not have specifically contributed to the oxidation of catechol and other intermediates, under the nutritional conditions employed, due to the greater molecular stability of the by-products.

The by-products generated from the dye degradation have recalcitrance, such as benzene, a highly stable and difficult-to-break compound ${ }^{11}$, as well as naphthalene, would have accumulated in $\mathrm{R} 2$, which requires new strategies to increase its potential and/or decrease their toxicity to microbial cells. Since glucose assimilation by microorganisms tends to occur very rapidly ${ }^{21}$, it would no longer be available in the medium, resulting in the difficulty of rupturing more complex bonds, with high values of dye removal occurred at the wavelength of the dye chromophore, which are simpler bonds.

\section{Dye and organic matter removal during the step II}

Figure 3 shows the concentration variation dye in the R1 and R2 reactors in step II. 


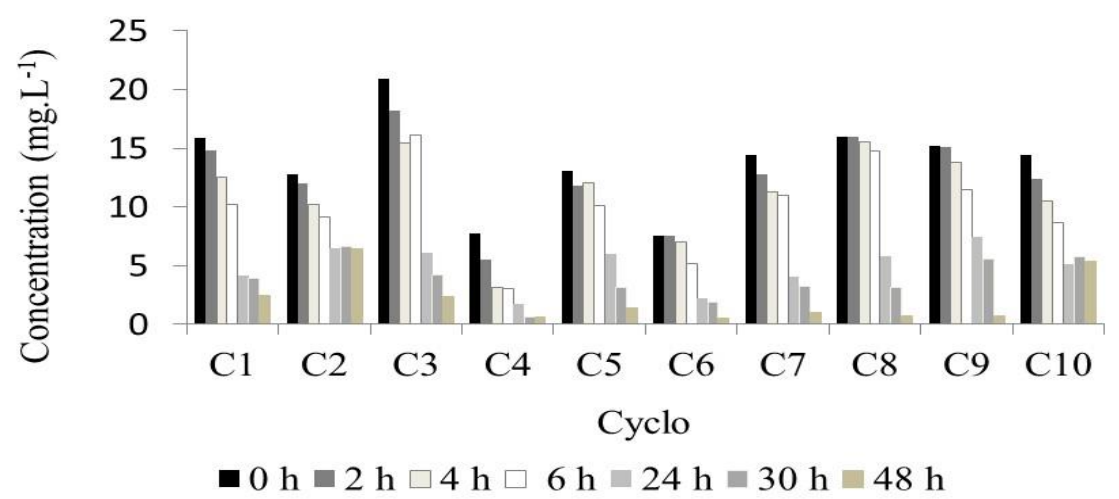

Figure 3 (a) - Variation of dye concentration in reactors with immobilized biomass of Phanerochaete chrysosporium in step II: (a) reactor R1 and (b) reactor R2.

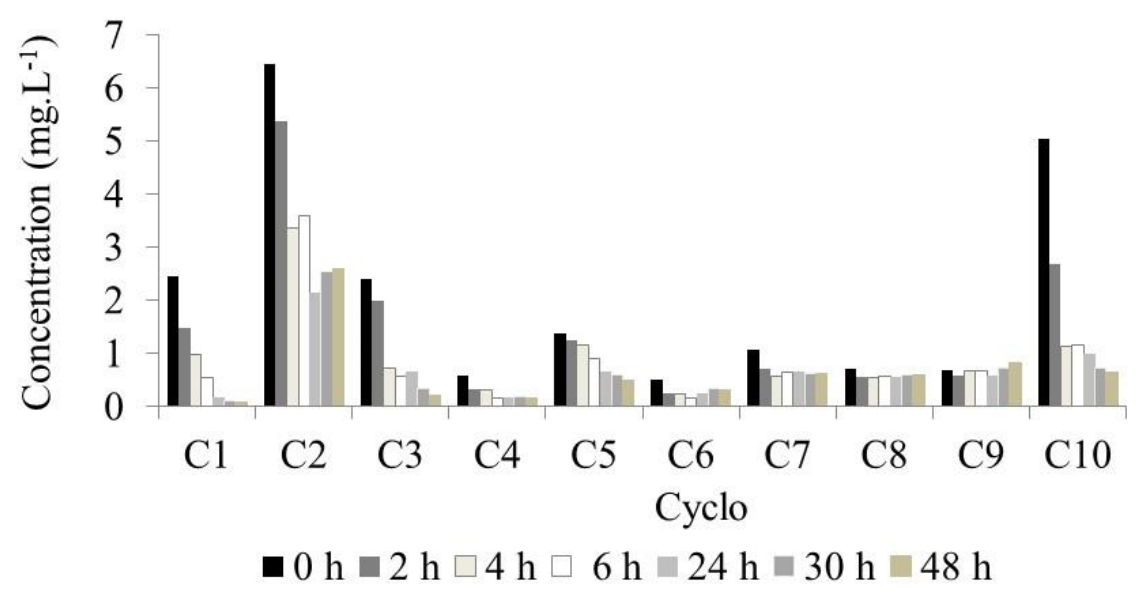

(b)

Figure 3 (b) - Variation of dye concentration in reactors with immobilized biomass of Phanerochaete chrysosporium in step II: (a) reactor R1 and (b) reactor R2.

The mean value of the influent dye in the $\mathrm{R} 1$ reactor was $14 \mathrm{mg} . \mathrm{L}^{-1}$, with the mean end-of-cycle effluent concentration of $2.2 \mathrm{mg} . \mathrm{L}^{-1}$ in this reactor. For the R2 reactor, the dye concentration in the effluent was $0.66 \mathrm{mg} . \mathrm{L}^{-1}$, thus observing an improvement in the red removal efficiency of the dye when compared to the previous step, which was due to the better performance of the reactor R1. In fact, R1 had a mean value of dye removal of $84 \% \pm 16$ in the 10 studied cycles, and the largest portion of congo red was particularly removed in this reactor.

Efficiencies from 50\% (2nd cycle) to 96\% (8th cycle) were achieved in reactor R1. During all reaction cycles, dye removal from the medium occurred, indicating the efficiency of this reactor in reducing the congo red concentration by $500 \mathrm{~nm}$. This better performance of $\mathrm{R} 1$ was attributed to the greater adaptation of the microorganisms to the substrate, since there was no change in the nutritional and operational conditions of the reactor.

As for the R2 reactor, the largest removal of congo red occurred in the second operating cycle $(18 \%)$, as observed by spectrophotometry at $500 \mathrm{~nm}$. The average dye removal recorded in $\mathrm{R} 2$ was $70 \% \pm 28$, to $500 \mathrm{~nm}$, the same percentage as in the previous step, when the glucose concentration in the tributary was 1 g.L. $\mathrm{L}^{-1}$. In this step, the overall efficiency achieved by the system for the removal of congo red varied from $80 \%$ (2nd cycle) to $99 \%$ (3rd and 4th and 7th cycle).

Although the concentration of glucose added to the influent of R1 was the same in both step I and step II, the average efficiency of dye removal in the second step (84\% 
$\pm 16)$ was higher than that recorded in the first step (76\%). This was reflected in the higher dye removal rate recorded in step II, when R1 presented a 1.6-fold higher velocity ( $\left.\mathrm{k}_{\text {obs }}: 0.07 \mathrm{~h}^{-1} ; \mathrm{R}^{2}: 0,952\right)$, that of step I ( $\left.\mathrm{k}_{\text {obs }}: 0.04 \mathrm{~h}^{-1} ; \mathrm{R}^{2}: 0,838\right)$. In the $\mathrm{R} 2$ reactor, a higher dye removal rate was achieved in Step I $\left(\mathrm{k}_{\mathrm{obs}}: 0.03 \mathrm{~h}^{-1} ; \mathrm{R}^{2}: 0,883\right)$, about 1.7 times higher than that recorded in step II ( $\left.\mathrm{k}_{\mathrm{obs}}: 0.02 \mathrm{~h}^{-1} ; \mathrm{R}^{2}: 0,832\right)$, despite of an average percentage of dye removal in step I (53\%) was higer than step II $(70 \% \pm$ 28).

However, the lowest $\mathrm{k}_{\mathrm{obs}}$ obtained in this reactor in step II may have been influenced by loss of efficiency in third and the last cycle (9th and 10th). The R2 showed some instability in the removal of the red from the remaining dye, since in some of the operating cycles increases of the dye concentration in the effluent of this reactor were observed specially in step I.

In step II, the R2 showed dye removal efficiency in almost all cycles that were monitored, ranging from 14 to $96 \%$, with dye concentration increase in terms of percentage points (pp) only in 9th cycle, 19 p.p., relative to the initial value. In step I, dye removal efficiency was obtained in 5 of the 8 monitored cycles, with variations from $1 \%$ to $21 \%$, emphasizing that there was an increase of the dye concentration in the medium, of 5pp. (3rd cycle), 4pp. (9th cycle) and 1pp. (10th cycle). It was not possible to monitor the decay profile of Congo red in the 1 st and 2 nd cycle. It was also observed that the day:glucose ratio affluent to the R2 reactor was 2:1 (step I) and 4:1 (step II), so that the dye concentration was 2 to 4 times higher than the amount of glucose available. In the R1 reactor, this ratio was $14: 1$, in both steps, resulting in a quantity of dye 14 times higher than that of glucose, a condition in which glucose would act as co-substrate, aiding in the use of the more complex carbon source.

However, it should be noted that in R2 there were in the middle other complex carbon sources, which also need to be considered in the adoption of the glucose concentration to be added, since the COD/dye ratio in R2 (123:1) was 2.5 times greater than R1 (50:1), which would indicate a greater presence of by-products and other compounds of the microbial metabolism in relation to the dye. It is probable that the aromatic fractions resulting from the rupture of the red congo molecule tend to persist in the medium, since the added glucose would be readily consumed ${ }^{21}$, involving the generation of reactive products that chromophore bonds, promoting its rupture and rapid discoloration of the medium ${ }^{22}$.

There was partial mineralization of the congo red in the effluent of the reactional cycles of R1, in both steps, but in a lower degree of mineralization of the aromatic fraction, with decrease of the absorbance in the relative wavelength of benzene (210 $\mathrm{nm}$ ) of $13 \%$ compared to the value recorded for the influent of the reactor. In step II, the reactor effluent R2, different from that observed in step I, did not show an increase in absorbance at wavelength relative to the aromatic fraction $(210 \mathrm{~nm})$, in relation to the affluent. A decrease of $22 \%$ in the absorbance value was measured at the influent of R1-R2 system without increasing the absorbance at the wavelength relating to naphthalene during the operational cycles of R2, as noted in step I, when glucose was added in higher concentration $\left(1 \mathrm{~g} . \mathrm{L}^{-1}\right)$.

When considering the absorbance values, measured in the affluent and R2 effluent, the decrease was $11 \%$. Although the apparent rate of dye consumption at R2 was higher in step I, its value was estimated based on the absorbance of the chromophore. Thus, even if dye removal was slightly faster in step I, this variable did not reflect the actual condition of the final effluent in relation to the mineralization of by-products formed, which was endorsed by the COD values in the final effluent of the system.

The use of glucose aided in reaching the good percentages of dye removal registered in this study, especially in R1. However, this removal was always related to the initial degradation of the dye molecule, without total mineralization of the pollutant. This was observed in the performed scans, which showed that the decrease in absorbance in 
the wavelengths of the other components of the molecular structure of the dye was lower than that of the chromophore $(500 \mathrm{~nm})$. The exception occurred in the reactor R2, which presented in step II similar removals for the absorbance measurement in the chromophore $(500 \mathrm{~nm})$ and in the benzene ring $(210 \mathrm{~nm})$, respectively, of $8 \%$ and $11 \%$.

The main function of $\mathrm{R} 2$ was the polishing of residual dye and by-products formed from its degradation, present in the effluent of R1. The concentration of glucose added influenced the initial rupture of the congo red molecule as well as the enzymatic production, with a slight decrease from $38 \mu \mathrm{mol} . \mathrm{min}^{-1}$ (step I) to $30 \mu \mathrm{mol} . \mathrm{min}^{-1}$ (step II), as well as less soluble COD removal, decreasing from $48 \% \pm 26$ (step I) to $20 \% \pm$ 10 (step II).

On the other hand, the lower availability of glucose $\left(0.5\right.$ g.L $\left.\mathrm{L}^{-1}\right)$ contributed to a higher mineralization of the $\mathrm{R} 2$ reactor effluent, whose spectrophotometric scanning in this condition presented decay in the wavelength of the aromatic fraction $(11 \%$ at $210 \mathrm{~nm})$. The higher concentration of glucose in step I ( 1 g.. $\left.\mathrm{L}^{-1}\right)$ may have contributed to the accumulation of aromatic intermediates in polishing reactor (R2) as the cos-substrate become the preferred source for consumption at the expense of aromatic intermediates. These intermediate compounds would be the last to be used by the microorganisms, since the enzymatic action would occur more easily at the chromophore binding.

Phanerochaete chrysosporium was used to remove congo red $\left(15 \mathrm{mg} . \mathrm{L}^{-1}\right)$ by using batch reactors with synthetic medium under agitation. The authors investigated the influence of carbon source and nitrogen on the efficiency of dye removal. $89 \%$ of dye removal was obtained in 15 days of operation, in the presence of $5 \mathrm{~g}$ of glucose per $\mathrm{L}^{23}$.

In the present study, average percentages of dye removal of $84 \% \pm 16$ were obtained in the R1 reactor, using a lower concentration of co-substrate (1 g. $\mathrm{L}^{-1}$ of glucose) and a lower reaction time (48 hours). This showed that the higher concentration of cosubstrate does not necessarily imply a greater removal of the dye, although the authors did not report if the glucose, at the concentration of 5 g.L.- would have aided in the degradation of the intermediate compounds formed. It was also verified the influence of adsorptive processes between the dye and the support material and the biofilm.

In step I, R1 removed a dye mass of $0.41 \mathrm{~g}$, which was higher than the mass required for the saturation of the carrier foam $(0.05 \mathrm{~g})$ and the mass absorbed to the mycelium $(0.09 \mathrm{~g})$. Thus, as the total adsorbed mass in the carrier and in the biofilm was $0.14 \mathrm{~g}$, the largest portion of the pollutant $(0.27 \mathrm{~g})$ was removed by biological action. In R2, as the mass of dye affluent was small, $0.006 \mathrm{~g}$ and $0.007 \mathrm{~g}$, respectively in steps I and II, it was not possible to measure the influence of the carrier material and mycelium on the retention of congo red by adsorption, since the dye concentration far below the capacity of these materials to adsorb it.

The mean value of the affluent dissolved COD to the R1 reactor was $809 \mathrm{mg} . \mathrm{L}^{-1}$. It is important to mention that the affluent values of organic matter to the $\mathrm{R} 2$ reactor were higher values than those found in the effluent of the R1 reactor, due to the addition of 0.5 g. $\mathrm{L}^{-1}$ of glucose. The R1 reactor showed an average removal of $70 \% \pm 20$ of this variable.

An average removal of $20 \% \pm 10$ of dissolved organic matter, with oscillations between $11 \%$ and $30 \%$, for the 10 cycles studied occurred in R2. The mean overall removal percentage for the system was $80 \%$. The comparison between the percent removal of dissolved COD and dye can indicate that the microorganisms were able to remove the dye and its by-products, as well as the added glucose as carbon source in both reactors.

The adsorption test on the polyurethane foam revealed that the material was capable of adsorbing $1.2 \mathrm{mg} \cdot \mathrm{g}^{-1}$. The dye adsorption assay on the biomass, performed after the 
end of the experiment, showed that the biomass was able to adsorb $7 \mathrm{mg} . \mathrm{g}^{-1}$. Thus, during the two study steps for reactor R1 were added to the reactor the total of 280.65 $\mathrm{mg}$ of dye. Discounting the amount of adsorption on the support medium (1.2 mg. $\left.\mathrm{g}^{-1}\right)$ and the biomass $\left(7 \mathrm{mg} \cdot \mathrm{g}^{-1}\right)$ present in the reactor, the dye affluent value was $36 \mathrm{mg}$ and the effluent value was $40.3 \mathrm{mg}$. In this way the biological removal promoted by the fungus resulted in $70 \%$.

By discounting the adsorbed dye mass in the biomass and the polyurethane foam of the reactor R2, theoretically, this phenomenon would be responsible for the removal of the residual concentration of dye from the $\mathrm{R} 1$ reactor during the steps that was 40.3 $\mathrm{mg}$. Thus, much of the adsorption occurred is due to the large amount of polyurethane foam in the reactor R2. However, enzymatic activity was recorded in this reactor, even with the low dye concentration in the affluent of each cycle $\left(2 \mathrm{mg} . \mathrm{L}^{-1}\right)$.

In this step the enzyme manganese-peroxidase (MnP) was found in low values, in both reactors, 2,6 $\mu \mathrm{mol} \cdot \mathrm{min}^{-1}$ (R1) and 2,3 $\mu \mathrm{mol} \cdot \mathrm{min}^{-1}$ (R2). However, laccase production was much higher than that of manganese peroxidase, with a maximum laccase activity of $30 \mu \mathrm{mol} . \mathrm{min}^{-1}$ in both reactors (R1 and R2). This value was lower than that obtained in step I for R1, when $54 \mu \mathrm{mol} \cdot \mathrm{min}^{-1}$ (R1) was detected, which coincided with the greater decrease of the absorbances measured in the affluent and effluent of this reactor for the benzene wavelength $(210 \mathrm{~nm})$ of $36 \%$. In step II, this value was $13 \%(210 \mathrm{~nm})$, with no increase in absorbance at the wavelength of naphthalene occurring.

The reduction in enzymatic activity in step II was observed to be only $21 \%$ in relation to that registered in step I, when the laccase activity was $38 \mu \mathrm{mol} . \mathrm{min}^{-1}$ in the same reactor. Similarly, the enzymes manganese peroxidase and laccase were used to discolor the amaranth, congo red and remazol blue brilliant $\mathrm{R}$ dyes and had higher activity of the laccase enzyme in detriment of manganese peroxidase ${ }^{15}$.

However, the authors emphasized the existence of a cooperative effect between the two in the process of dye degradation. In addition, the affinity of these enzymes for the structure of the dye is another factor that may contribute to differences in the behavior of the enzymatic activity ${ }^{24}$. Apparently, laccase had a direct effect on the removal of the aromatic fraction from the dye molecule in R1, since there was a higher production of laccase when a greater benzene removal of 36\% was achieved in step I, with a color/glucose ratio of 14:1. On the other hand, the effluent of R1 in step II showed a greater presence of benzene compounds and other by-products of dye degradation.

The presence of these compounds implied in the lower efficiency of R2, both in relation to the chromophore and the aromatic fraction that would have accumulated in this second reactor, with a color/glucose ratio of $2: 1$. This accumulation, as verified in the sweep made with the effluent samples, was justified by the low ionization potential of these compounds in the nutritional conditions of the medium. In spite of the lower enzymatic activity recorded in step II, which resulted in the lower decrease in the relative absorbance of benzene in the influent and effluent of the R1 reactor (13\%), there was no accumulation of aromatic by-products in $\mathrm{R} 2$.

Although the dye removal efficiency at the chromophore wavelength was low (8\%), in $\mathrm{R} 2$, in this condition (dye: glucose of 4:1), the mineralization of sub-products in the effluent R2 was higher, without accumulation of aromatic compounds, indicating that higher concentrations of glucose are unsuitable for their mineralization. The addition of co-substrate to pulses over longer operating cycles could be a tool for further study, since the use of co-substrate is important for the biodegradation process, as it assists the enzyme and facilitates the assimilation of the pollutant by the generation of high reactivity compounds ${ }^{22}$. 


\section{CONCLUSIONS}

The use of Phanerochaete chrysosporium inoculated in sequential batch reactors with arranged in series produced a colorless effluent. However, no rupture of the aromatic fraction of the congo red molecular structure was observed and resulted in the formation of aromatic by-products in the medium. The highest dye and organic matter removal was recorded in R1 in both steps was attributed to the highest enzymatic production, particularly laccase.

The mineralization of aromatic intermediates was influenced by the dye/glucose ratio. For higher values of this relation there was a greater decrease of the spectral bands related to the aromatic intermediates present in the final effluent. Although the degree of mineralization was small, as seen in R2, no accumulation of aromatic by-products was observed as occurred in reactor $\mathrm{R} 1$. The largest portion of congo red was removed by biological pathway.

The use of fungi in reactors for the biodegradation of textile dyes requires the development of strategies as how to add the co-substrate or the type of the substance used as co-substrate in order to further the mineralization of the aromatic fraction. It is important to increase the ionization potential of these by-products by the degradative enzymes.

\section{ACNOWLEDGES}

Acknowledges to the National Council for Scientific and Technological Development (CNPq) - Brazil for financial assistance Process no. 479374/2012-0.

\section{REFERENCES}

1. Minillo A., Isique W. D., Prado H. F. A., Tangerino E. P. Biodegradação de fármacos na água por microrganismos associados em filtros biológicos de carvão. Rev DAE. 2009; 179:42 49.

2. Paschoal F. M. M., Tremiliosi-Filho G. Aplicação da tecnologia de eletrofloculação na recuperação do corante índigo blue a partir de efluentes industriais. Química Nova. 2005; 28 : 766-772.

3. Corso C.R., Almeida A.C.M. Bioremediation of dyes in textile effluents by Aspergillus oryzae. Microb Ecol. 2009; 57: 384- 390.

4. Souza S.M.A.G., Bonilla K.A.S., Ulson de Souza A.A. Removal of COD and color from hydrolyzed textile azo dye by combined ozonation and biological treatment. 2010. J Hard Mater. 2010; 179: 35-42.

5. Gomes E., Aguiar A.P., Carvalho C.C., Bonfa M.R.B., Silva, R., Boscolo M. Ligninases production by basidiomycetes strains on lignocellulosis agricultural residues and their application in the decolorization of synthetic dyes. Braz J Microbiol. 2009; 40: 31-39.

6. Gopinath K. P., Muthukumar K., Velan M. Sonochemical degradation of congo red: Optimization through response surface methodology. Chem Eng J. 2010; 157:427 - 433.

7. Bergsten-Torralba L.R., Nishikawa M.M, Baptista D.F., Magalhães D.P., Da Silva M. Decolorization of different textile dyes by Penicillium simplicissimum and toxicity evaluation after fungal treatment. Braz J Microbiol, 2009; 40: 808-817.

8. Rodrigues K., Lima K. M., Silva G.M.M., Silva G., Cunha, P., Pessoa, R. Remoção de corante por uso de Aspergillus niger AN400 em reator em bateladas sequenciais. Quím Nova. 2011; 34: 119-1123.

9. Andrade, M. V. F. Biodegradação de corante têxtil em reatores fúngicos operados em série e em bateladas sequenciais. 94p. Dissertação (Pós-graduação em Tecnologia e Gestão Ambiental do Instituto Federal do Ceará). 2013.

10. Santos, A. D. O., Souza, A. M. X., Barreto, I. N., Wanderley, C. R. P., Marinho, G. Rodrigues. K. Degradação de índigo carmim em reator em bateladas sequenciais com 
Aspergillus niger AN400 no tratamento de água residuária têxtil in natura. Rev Ingeniería y Ciencias Ambientales: Investigación, desarrollo y prática. 2015; 8: 328-343.

11. APHA. Standard methods for the examination of water and wastewater. 20a. ed. Washington: American Public Health Association; 2005.

12. Aguiar Filho J. M. M., (2008). Enzymatic analysis of lignocellulolytic fungi grown in vinasse and sugarcane bagasse. 2008. 80. Dissertation (Master). Luiz de Queiroz College of Agriculture - São Paulo.

13. Martins M. A. M., Queiroz M. J., Silvestre A. J. D., Lima N. Relationship of chemical structures dyes on the pre-adaptation medium and the potentialidades of their biodegradation by Phanerochaete chrysosporium. Res Microbiol. 2002; 153: $361-368$.

14. Kumar R., Sinha, A., Mondal, G. C., Masto, R. E. Effective scrap iron particles (sip) pretreatment for complete mineralization of benzidine based azo dye effluent. Arab J Chem. 2017. http://dx.doi.org/10.1016/j.arabjc.2017.03.001.

15. Champagne, P. P., Ramsay, J. A. Contribution of manganese peroxidase and laccase to dye decoloration by Trametes versicolor. Appl Microbiol Biotechnol. 2005; 69: 276 - 285.

16. Bagewadi, Z. K., Mulla S. I., Ninnekar, H. Z. Purification and immobilization of laccase from Trichoderma harzianum strain HZN 10 and its application in the dye decolorization. J Genetic Eng and Biotechnol. 2017; 15: 139 - 150.

17. Zillle, A., Maunteanu, F. D., Gübitz, G. M., Cavaco-Paulo A. Laccase kinetics of degradation of coupling reactions. J Mol Catal B: Enzym. 2005; 33: 23 - 28.

18. Das A., Bhattacharya, S., Panchanan, G., Navya, B. S., Nambiar P. Production, characterization and congo red dye decolorizing efficiency of a laccase from Pleurotus ostratus MTCC 142 cultivated on co-substrates of paddy straw and corn husk. J Genet Eng Biotechnol. 2016; 14: $281-288$.

19. Mistry, B. D. A handbook of spectroscopic data Chemistry. Jaipur, India: Oxford Book Company; 2009.

20. Wang, N., Chu Y., Wu F., Zhao Z., Xu, X. Decolorization and degradation of congo red by newly isolated white rot fungus Ceriporia lacerata from decayed mulberry branches. Inter Biodeter Biodegr. 2017; 117: 236-244.

21. Rodrigues K. A., Sampaio G. M. S., Zaiat M., Santaella S. T. Influência da glicose sobre o consumo de fenol por Arspergillus niger AN400 em reatores em batelada. Rev Eng Sanit Amb. 2007; 12: 222 - 228.

22. Singh H. Mycoremediation: Fungal Bioremediation. Canada: Wiley; 2006.

23. Pant D., Singh A., Satyawali Y., Gupta R. K. Effect of carbon and nitrogen source amendment on synthetic dyes decolourizing efficiency of white-rot fungus, Phanerochaete chrysosporium. J Environ Biol, 2008: 29: 79-84.

24. Pasti-Grigsby M. B., Paszczynski A., Goszczynski S., Crawford D. L., Crawford R. L. (1992). Influence of aromatic substitution patterns on azo dye degradability by Streptomyces spp. and Phanerochaete chrysosporium. Appl Environ Microbiol. 1992; 58: 3605-3613. 